\title{
Owen Ridge deep-water submarine landslides: implications for tsunami hazard along the Oman coast
}

\author{
M. Rodriguez ${ }^{1,2,3}$, N. Chamot-Rooke ${ }^{3}$, H. Hébert ${ }^{4}$, M. Fournier ${ }^{1,2}$, and P. Huchon ${ }^{1,2}$ \\ ${ }^{1}$ Institut des Sciences de la Terre de Paris, UMR7193, Université Pierre et Marie Curie, case 129, 4 place Jussieu, \\ 75252 Paris cedex 05, France \\ ${ }_{2}^{2}$ iSTeP, UMR7193, CNRS, 75005 Paris, France \\ ${ }^{3}$ Laboratoire de Géologie, Ecole normale supérieure, 24 rue Lhomond, 75231 Paris cedex 05, France \\ ${ }^{4}$ CEA, DAM, DIF, 91297 Arpajon, France
}

Correspondence to: M. Rodriguez (rodriguez@geologie.ens.fr)

Received: 25 September 2012 - Published in Nat. Hazards Earth Syst. Sci. Discuss.: -

Revised: 15 January 2013 - Accepted: 19 January 2013 - Published: 15 February 2013

\begin{abstract}
The recent discovery of voluminous submarine landslides along the Owen Ridge may represent a source of tsunami hazard for the nearby Oman coast. We assess the severity of this potential hazard by performing numerical simulations of tsunami generation and propagation from the biggest landslide $\left(40 \mathrm{~km}^{3}\right.$ in volume) $\mathrm{ob}-$ served along the Owen Ridge. A finite-difference model, assimilating the landslide to a visco-plastic flow, simulates tsunami generation. Computation results show that Salalah city (190000 inhabitants) is impacted by $2.5 \mathrm{~m}$-high tsunami waves one hour after sediment failure. Higher wave elevation values $(4 \mathrm{~m})$ are reached in the low populated Sawqara Bay over $80 \mathrm{~min}$ after slide initiation. Although large submarine failures along remote oceanic ridges are infrequent, this study reveals an underestimated source of tsunami hazard in the Arabian Sea.
\end{abstract}

\section{Introduction}

Arabian Sea coasts have been affected by numerous and disastrous tsunamis in the past (Jourdan, 2008; Heidarzadeh et al., 2008; Donato et al., 2008, 2009; Jaiswal et al., 2009; Pilarczyk et al., 2011; Pilarczyk and Reinhardt, 2012) and storm waves from cyclones (Fritz et al., 2010). The main tsunami source in the Arabian Sea is the seismic activity of the Makran subduction zone, which caused the 1945 event $\left(M_{\mathrm{w}}=8.1\right)$ and the subsequent 4000 human fatalities. Other far field sources, such as the seismic activity of the In- donesian subduction zone, may generate modest tsunamis on Arabian Sea coastlines (Okal et al., 2006). Although previous studies have identified submarine landslides as the source of some of the deadliest tsunamis over the last decades (for instance the 1998 Papua New Guinea event (Heinrich et al., 2000; Tappin et al., 2001, 2008)), the severity of such hazard remains unknown in the Arabian Sea.

Tsunamis are dispersive gravity water waves with a phase velocity $c=\sqrt{ } g h$ at long period, where $h$ is the bathymetry and $g$ the gravitational acceleration. Submarine landslidegenerated tsunamis display distinct differences compared to earthquake-generated tsunamis (Trifunac and Todorovska, 2002): because of their smaller source dimensions, landslidegenerated tsunamis are more affected by frequency dispersion, resulting in shorter wavelength and faster wave amplitude attenuation. However, vertical displacements at the source can be larger in comparison to earthquake source, and lead to potentially higher amplitude waves, which requires the consideration of non-linearity of the propagating waves.

The recent discovery of voluminous submarine landslides along the Owen Ridge may represent an under-estimated source of tsunami hazard in the Arabian Sea (Fournier et al., 2011). The Owen Ridge is a prominent submarine relief located 300 to $400 \mathrm{~km}$ away from the coast of Oman and is closely linked to the Owen Fracture Zone, a $800 \mathrm{~km}$ long active strike-slip fault system (Rodriguez et al., 2011; Bourget et al., 2013) (Fig. 1). Several types of mass failures have been mapped in details along the ridge using multibeam bathymetry and sediment echo-sounder (Rodriguez et 


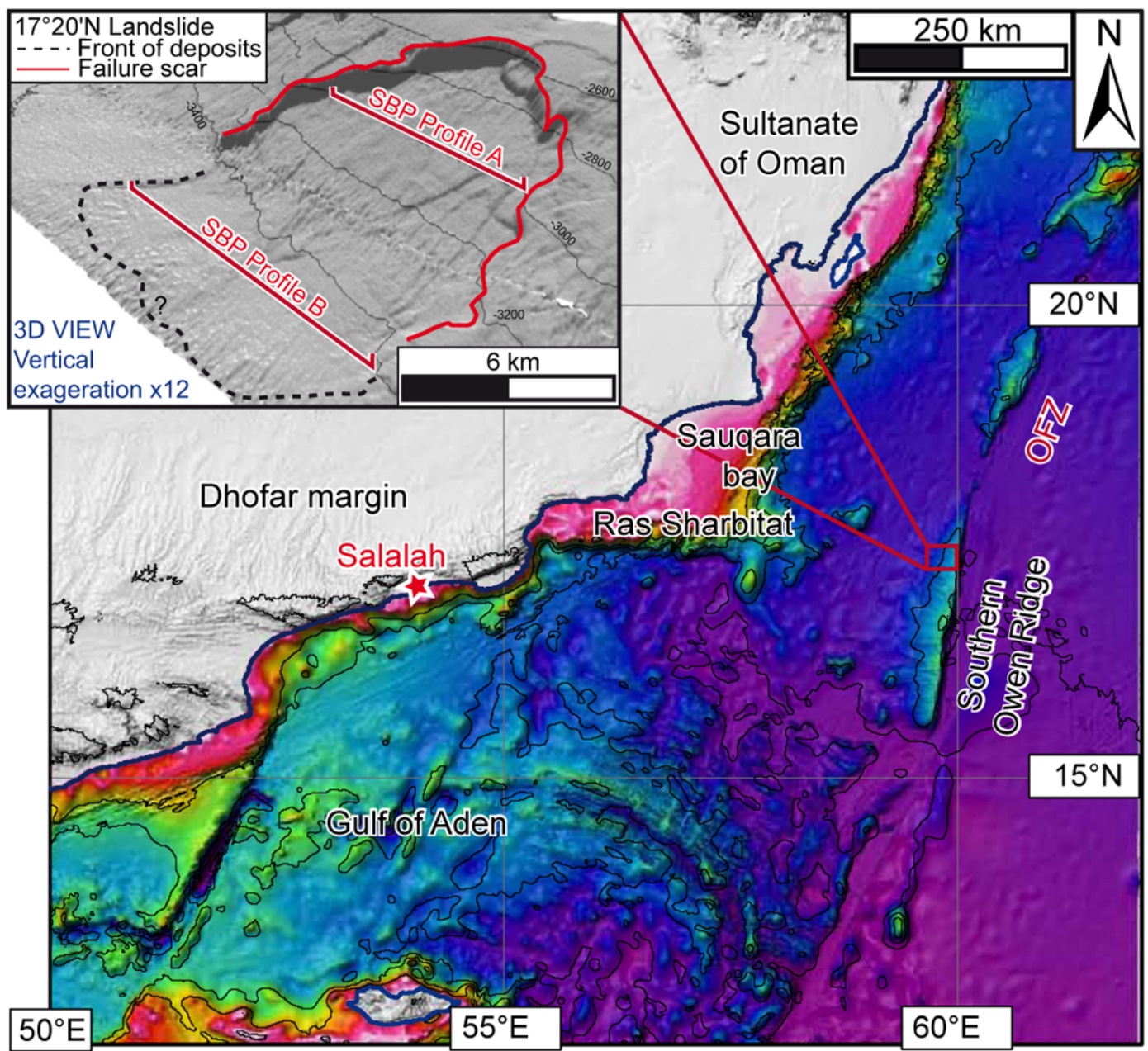

Fig. 1. Regional topographic map of the Sultanate of Oman and the offshore Owen Fracture Zone. Inset shows a $3-\mathrm{D}$ view of the $17^{\circ} 20^{\prime} \mathrm{N}$ landslide located on the Owen Ridge. OFZ: Owen Fracture Zone.

al., 2012). The southern segment of the Owen Ridge displays the most voluminous landslides, including two landslides that removed up to $40-45 \mathrm{~km}^{3}$ of sediment according to their failure morphology (Rodriguez et al., 2012). To date, there are neither historical witnesses of a tsunami nor tsunami deposits on the Oman coast that can be related to a mass-wasting episode over the Owen Ridge (Pilarczyk et al., 2011; Hoffman et al., 2013). In contrast with subaerial or shallow landslides (Fritz et al., 2009; Mohammed and Fritz, 2012), the tsunami hazard associated with deepsea $(>2000 \mathrm{~m}$ ) landslides remains poorly investigated (Lo lacono et al., 2012). The objective of this paper is to assess the severity of this potential source of tsunami hazard along the nearby Oman coasts, by modelling the generation, propagation, and heights from tsunamis triggered by the biggest submarine landslide (located at the latitude of $17^{\circ} 20^{\prime} \mathrm{N}$ ) on the southern segment of the Owen Ridge.

\section{Geological background and description of the $17^{\circ} 20^{\prime} \mathrm{N}$ submarine landslide}

The Owen Ridge is composed of three distinct bathymetric highs running parallel to the Owen Fracture Zone, including the $300 \mathrm{~km}$-long, $50 \mathrm{~km}$-wide, and $2000 \mathrm{~m}$-high asymmetric southern Owen Ridge (Fig. 1). The southern Owen Ridge is covered by a $\sim 500 \mathrm{~m}$ thick pelagic drape, mainly made up of nanno-fossil ooze and clays (Shipboard scientific party, 1989). The regular western slope of the Owen Ridge, corresponding to sedimentary beds gently tilted $2-3^{\circ}$ to the west, favours the occurrence of large retrogressive slumps with 25 events mobilizing more than $1 \mathrm{~km}^{3}$ of sediments observed on the seafloor (Rodriguez et al., 2012). The relative arrangement of slope failures and mass transport deposits along the southern ridge reveals that each slide occurred as a distinct event. Stratigraphic studies document sporadic mass wasting events through time since the uplift of the Owen Ridge in the Miocene, with a typical recurrence rate of the 

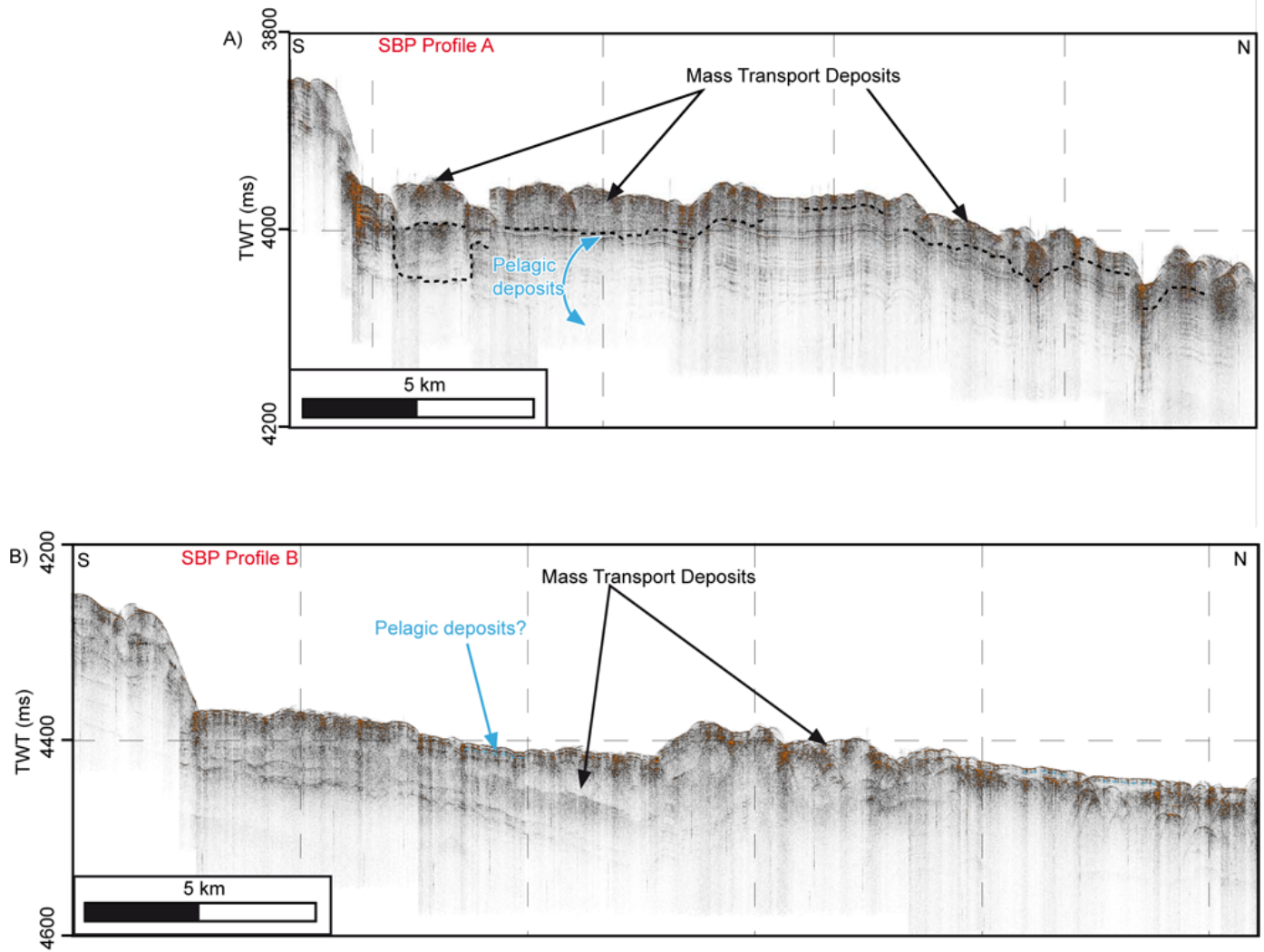

Fig. 2. $3.5 \mathrm{kHz}$ echo-sounder profiles (SBP 120) across the $17^{\circ} 20^{\prime} \mathrm{N}$ landslide. See Fig. 1 for location. Vertical exaggeration $x 28$.

order of $10^{5}-10^{6} \mathrm{yr}$ (Rodriguez et al., 2012). The recurrence rate is determined by converting into time the thickness of pelagic deposits lying between successive mass transport deposits according to sedimentation rates calculated at ODP sites (Shipboard Scientific Party, 1989; Rodriguez et al., 2012). The seismicity along the Owen Fracture Zone is rather low and scattered (Quittmeyer and Kafka, 1984; Gordon and DeMets, 1989; Fournier et al., 2001), the maximum magnitude recorded to date being a $M_{\mathrm{w}}=5.3$ earthquake (Harvard CMT, 7 April 1985). However, millennial large earthquakes $\left(M_{\mathrm{w}} \sim 7\right)$ are expected (Fournier et al., 2008; Rodriguez et al., 2012) as reported at other oceanic fracture zones. Although earthquakes are the most likely triggering factor of slope failure, the apparent discrepancy between earthquake frequency and mass wasting frequency highlights the dominant control of slow pelagic sedimentation rates and hence, time needed to return to a mechanically unstable pelagic cover (Rodriguez et al., 2012).

Because the speed of the failed mass strongly affects the amplitude of the out-going wave (Trifunac and Todorovska, 2002), it is important to determine the kinematics of the landslide, i.e., whether the mass movement is a slump or a debris flow. Based solely on multibeam bathymetry and echosounder data, it is ambiguous to solve the latter problem as mass movement type is usually assessed by rigorous core analyses (Mulder and Cochonat, 1996; McAdoo et al., 2000; Tripsanas et al., 2008). Nevertheless, mapping the architecture of sediment failures using subsurface data provides fundamental constraints on numerical models of tsunami generation (Tappin, 2010).

The landslide located at $17^{\circ} 20^{\prime} \mathrm{N}$ is the biggest landslide (volume $=40 \mathrm{~km}^{3}$ ) that occurred along the southern Owen Ridge (Fig. 1) (Rodriguez et al., 2012). In this area, the failure initiates at $2000 \mathrm{~m}$ water depth, and a $400 \mathrm{~km}^{2}$ area of hummocky seafloor, characterised by a chaotic facies on echo-sounder profiles (SBP120), is partly enclosed by a $35 \mathrm{~km}$-long arcuate failure scar (Figs. 1, 2). This description of the $17^{\circ} 20^{\prime} \mathrm{N}$ failure suggests a sedimentary material remaining close to the slide scar and hence a cohesive motion of the transported mass (such as in slump processes) rather than a disintegrative motion (such as in debris flow processes). Consequently, we modelled the $17^{\circ} 20^{\prime} \mathrm{N}$ landslide as a homogeneous visco-plastic flow subjected to gravity. The age of the $17^{\circ} 20^{\prime} \mathrm{N}$ landslide can be roughly inferred by converting into time the thickness of pelagic deposits that blankets mass transport deposits downslope (Fig. 2). By taking into account sedimentation rates of the order of $40 \mathrm{~m} \mathrm{Myr}^{-1}$ (Shipboard scientific party, 1989), the $\sim 5.4 \mathrm{~m}$ thick pelagic cover indicates an age for the $17^{\circ} 20^{\prime} \mathrm{N}$ deposits around $130 \mathrm{kyr}$. 


\section{Methods}

\subsection{Multi-beam bathymetry}

Multi-beam bathymetry was collected using a hull-mounted Kongsberg-Simrad EM120 multi-beam echosounder during the OWEN 2009 survey onboard the French R/V BeautempsBeaupré (Fournier et al., 2011). The vertical resolution of the swath bathymetric data is of the order of $10 \mathrm{~m}$. The dataset allows the production of maps at a $80 \mathrm{~m}$ grid interval. It was combined with the SRTM grid at $30^{\prime \prime}$ to produce a uniform digital elevation model (DEM) at $1 \mathrm{~km}$ grid spacing (datum:WGS 84). The DEM was then used for the source sensitivity studies and to investigate the impact of landslidegenerated tsunami on the Arabian Sea coasts. Although the DEM includes the coastline, it is however not refined in its shallowest bathymetric part and in the first emerged meters. Thus the only estimations provided in the following consist of maximum water heights close to the coast, but do not provide any detailed mappings of flooding.

\subsection{Landslide modelling}

We use the AVALANCHE code that has been described in details and successfully tested for the 1998 Papua New Guinea event (Heinrich et al., 2001) and the 1979 Nice event (Labbé et al., 2012). The model is based on the shallow water assumption, with slide thickness much smaller than its length and width. This approach allows us to ignore the exact mechanical behaviour within the flow (Savage and Hutter, 1989). The mechanism initiating the landslide is not investigated in this study and it is assumed that the whole mass suddenly loses its equilibrium and begins to flow down the slope. Modelling the $17^{\circ} 20^{\prime} \mathrm{N}$ landslide as a viscous flow requires a parabolic profile of the slope-parallel velocity of the sedimentary mass, with a no-slip condition at the sea bottom (Jiang and Leblond, 1992). The shear stress $\tau_{x z(z=0)}$ at the sea bottom is expressed as

$\boldsymbol{\tau}_{x z(z=0)}=-3 \mu \boldsymbol{u} / h \rho_{\mathrm{s}}$

where $\mu$ is the dynamic viscosity, $\boldsymbol{u}$ the slide velocity, $\mathrm{h}$ the slide thickness perpendicular to the slope, and $\rho_{\mathrm{s}}$ the sediment density.

As viscous flows never stop on the sea bottom whatever the viscosity coefficient, it is necessary to model the $17^{\circ} 20^{\prime} \mathrm{N}$ landslide as a visco-plastic fluid (also called a Bingham plastic fluid). In a visco-plastic fluid, no deformation takes place until a specified shear stress, called the yield stress, is applied to the fluid. Above the yield stress, the material flows like a viscous fluid (Jiang and Leblond, 1993). By considering that equations are averaged through the thickness of the slide, the Bingham model requires two systems of equations to be solved, corresponding to two distinct zones in the flow, a shear flow driven by viscosity and a plug flow above it with a uniform velocity profile (Jiang and Leblond, 1993). Since the slide thickness ( $140 \mathrm{~m}$ at the initiation) is much smaller than the slide length in the case study, the Bingham model can be simplified by considering a single layer whose motion is initiated and driven by viscosity when the shear stress exceeds a given yield stress (Norem et al., 1991; McEwen and Malin, 1989). The resulting equations of mass and momentum conservation, written in a coordinate system linked to the topography, read (see Heinrich et al., 2001)

$$
\begin{aligned}
& \frac{\partial h}{\partial t}+\frac{\partial}{\partial x}(h \boldsymbol{u})+\frac{\partial}{\partial y}(h v)=0 \\
& \frac{\partial}{\partial t}(h \boldsymbol{u})+\alpha \frac{\partial}{\partial x}(h \boldsymbol{u} \cdot \boldsymbol{u})+\alpha \frac{\partial}{\partial y}(h \boldsymbol{u} \cdot v) \\
& =-\frac{1}{2} \boldsymbol{\kappa} \frac{\partial}{\partial x}\left(g h^{2} \cos \theta\right)+\boldsymbol{\kappa} g h \sin \theta_{x}-\boldsymbol{\tau}_{x z(z=0)} \\
& \frac{\partial}{\partial t}(h v)+\alpha \frac{\partial}{\partial x}(h v \cdot \boldsymbol{u})+\alpha \frac{\partial}{\partial y}(h v \cdot v) \\
& =-\frac{1}{2} \boldsymbol{\kappa} \frac{\partial}{\partial y}\left(g h^{2} \cos \theta\right) \\
& +\boldsymbol{\kappa} g h \sin \theta_{y}-\boldsymbol{\tau}_{y z(z=0)}
\end{aligned}
$$

where $\boldsymbol{\kappa}=1-\rho_{w} / \rho_{s}, \tau_{x z(z=0)}$ and $\tau_{x y(z=0)}$ are the shear stresses at the bed surface, $\boldsymbol{u}=(\boldsymbol{u}, \mathrm{v})$ is the depth-averaged velocity vector parallel to the bed, $h$ is the slide thickness perpendicular to the slope, $\rho_{w}$ and $\rho_{s}$ are the water and sediments densities with a ratio $\rho_{w} / \rho_{s}=2, \theta(\mathrm{x}, \mathrm{y})$ is the local steepest slope angle, $\theta_{x}$ and $\theta_{y}$ are the slope angles along $\mathrm{x}$ and y-axes, respectively. Values of $\alpha$ that deviate from unity provide information about the deviation of the slope normal profile of $(\mathrm{u}, \mathrm{v})$ from uniformity. These hyperbolic equations are solved in the same numerical scheme as the one used in the tsunami model.

\subsection{Tsunami modelling}

Simulations of the tsunami waves are based on the shallowwater approximation, which deals with the full interaction of landslide and water, including the deformation of the sediment body. Equations governing the landslide and the tsunami propagation are similar and non-dispersive. They are thus solved using the same Godunov-type scheme, extended to second order by using the concept of Vanleer (Alcrudo and Garcia-Navarro, 1993; Mangeney et al., 2000), which is based on a shock-capturing method originally derived from gas dynamics models (Heinrich et al., 2001). This model is particularly adapted to deal with nonlinear waves. The sea bottom deformation through time resulting from the landslide motion is introduced as a known forcing term $(\cos \theta)^{-1} \partial h / \partial t$ in the mass conservation equation of the tsunami model. Finally, our model also allows the computation of inundation (run-up) heights at the receiving shore.

\section{Results}

Several sensitivity tests of parameters were performed. The major parameter controlling tsunami generation is the cohesion of sediment within the flow, tsunami being generated 
for cohesion less than $40 \mathrm{~g} \mathrm{~m}^{-3}$. Simulations have been carried out for dynamic viscosity values ranging between 25 and $500 \mathrm{~m} \mathrm{~s}^{-2}$, consistent with observations of subaerial debris avalanches (Sousa and Voight, 1991, 1995). For a fixed cohesion value, the dynamic viscosity of the flow has no significant impact on the slide motion and therefore on the wave field pattern. Values of dynamic viscosity ranging between 250 and $500 \mathrm{~m} \mathrm{~s}^{-2}$ better reproduced the observed extension of mass transport deposits. About $400 \mathrm{~s}$ after slide initiation, the resulting average velocities of the landslide reach $\sim 40 \pm 3 \mathrm{~m} \mathrm{~s}^{-1}$.

At the source location, the original radiated wave is formed of two peaks and one trough. The water ahead of the front face of the slide is pushed away, creating a leading positive wave in the slide direction. The trough following the crest is simultaneously created by the slide excavation, and is followed by a large second positive peak created by the infilling of the trough (Fig. 3). In spite of the $\sim 2000 \mathrm{~m}$ water depth of slide initiation, water heights at the source can reach $4.8 \mathrm{~m}$ in elevation, the highest waves being formed in the out-going direction of the slide, thus towards the Oman coast. Amplitudes of the back-going waves are reduced and significantly attenuated only $8 \mathrm{~km}$ east from the source. The three out-going waves spread away from the source as cylindrical waves (Fig. 3). The tsunami wave field mainly affects Oman coasts, other areas being too far from the source. The time for the first leading wave to reach the Oman coastline at Ras (cape) Madrakah is 35 min (Fig. 3). The complex bathymetric pattern related to the transition between the Oman transform margin (between $18^{\circ} \mathrm{N}$ and $22^{\circ} 30^{\prime} \mathrm{N}$ ) and the rifted margins of the Gulf of Aden strongly influences the propagation of the tsunami wave field (Figs. 1, 3). Indeed, Hasik town and Salalah city are impacted by the tsunami 43 and $60 \mathrm{~min}$ after the submarine failure, respectively, whereas Ras Sharbitat, closer to the tsunami source, is impacted after $80 \mathrm{~min}$ of tsunami propagation (Fig. 3). This delay is due to the $\sim 120 \mathrm{~km}$ wide continental shelf at the latitude of Ras Sharbitat, which slows down the propagation of the tsunami. Because of reduced continental shelves, the coastlines of the eastern Gulf of Aden are impacted earlier.

In order to investigate the behaviour of tsunami waves obtained for the maximum scenario, we plot the maximal water heights reached after a $2 \mathrm{~h}$ propagation time in the whole computational domain (Fig. 4). This map indicates the spatial distribution of the tsunami energy along Oman coastlines and reveals additional bathymetric forcing. First, numerous canyons that dissect the slope between $18^{\circ}$ and $20^{\circ} \mathrm{N}$ locally amplify the wave elevation up to $2 \mathrm{~m}$. Second, the Sharbitat Ridge, which is an E-W rectilinear, $\sim 140 \mathrm{~km}$-long submarine extension of the Oman margin located at the entrance of the Gulf of Aden, strongly influences the tsunami propagation and amplifies wave elevation up to $6 \mathrm{~m}$ (Fig. 4). The most affected area is the Sauqara Bay (between $18^{\circ}$ and $19^{\circ} \mathrm{N}$ ) with water heights reaching $2.5 \mathrm{~m}$ at the coastline, locally $4 \mathrm{~m}$ in the vicinity of Ras Sharbitat. Locally, tsunami waves
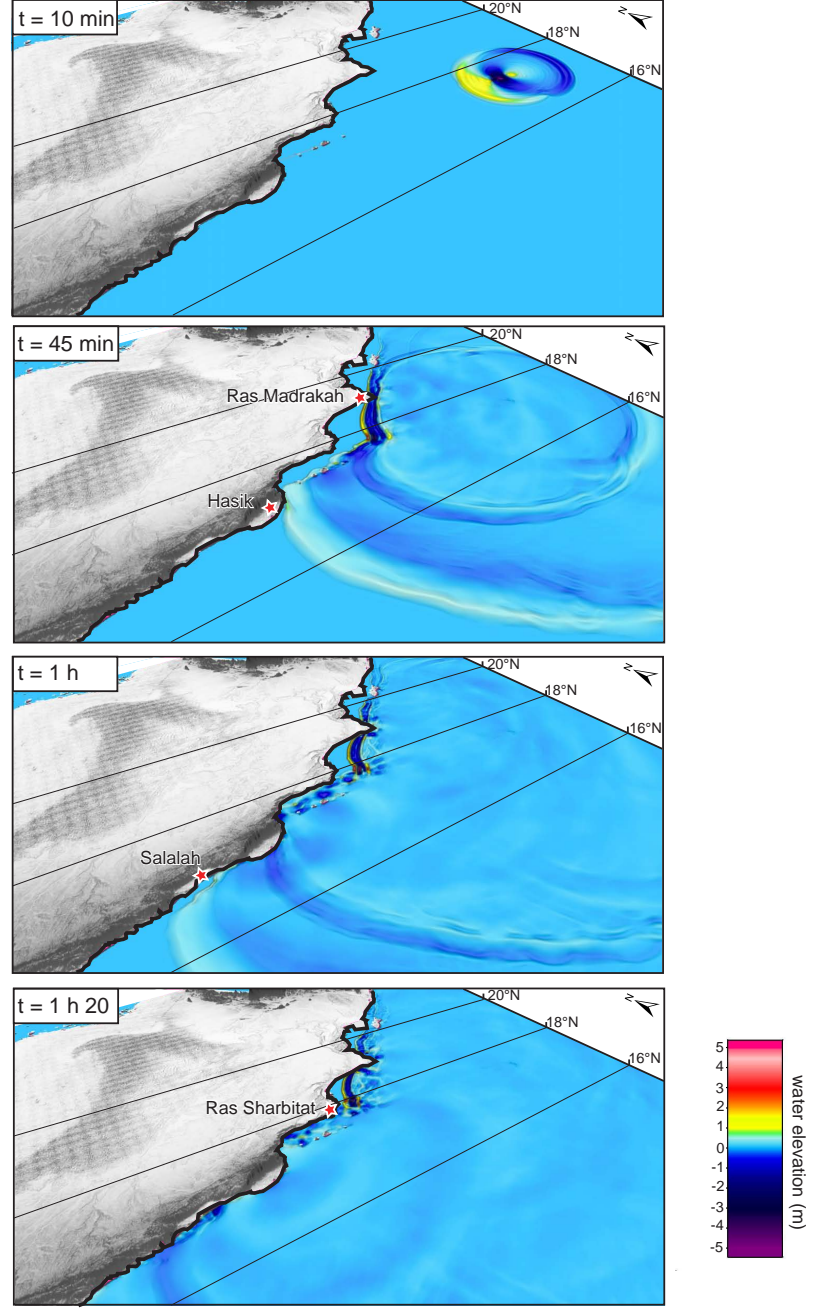

Fig. 3. Snapshots of the computed water surface for a dynamic viscosity value at $500 \mathrm{~m} \mathrm{~s}^{-2}$. Vertical scale is exaggerated by a factor of 20 with respect to horizontal scale.

on the order of $1 \mathrm{~m}$ impact the coastline of the Masirah Bay. Run-up values of $\sim 2 \mathrm{~m}$ are calculated at Salalah, the most populated city of the area.

\section{Discussion and conclusions}

Numerical results show that a submarine landslide similar to the one that occurred at $17^{\circ} 20^{\prime} \mathrm{N}$ on the Owen Ridge can produce moderate tsunamis along the Oman east coast. Such tsunamis would impact industrialised but low populated areas, except for the city of Salalah (190000 inhabitants) in the Gulf of Aden and the newly built Port of Duqm on the east Oman coasts. Maximum calculated wave height values along the east Oman coasts would be of the same order as run-up values reported for the 2004 Indonesian transoceanic event for the same coasts ( 0.7 to $3.3 \mathrm{~m}$ ) (Okal et al., 2006; Okal and 


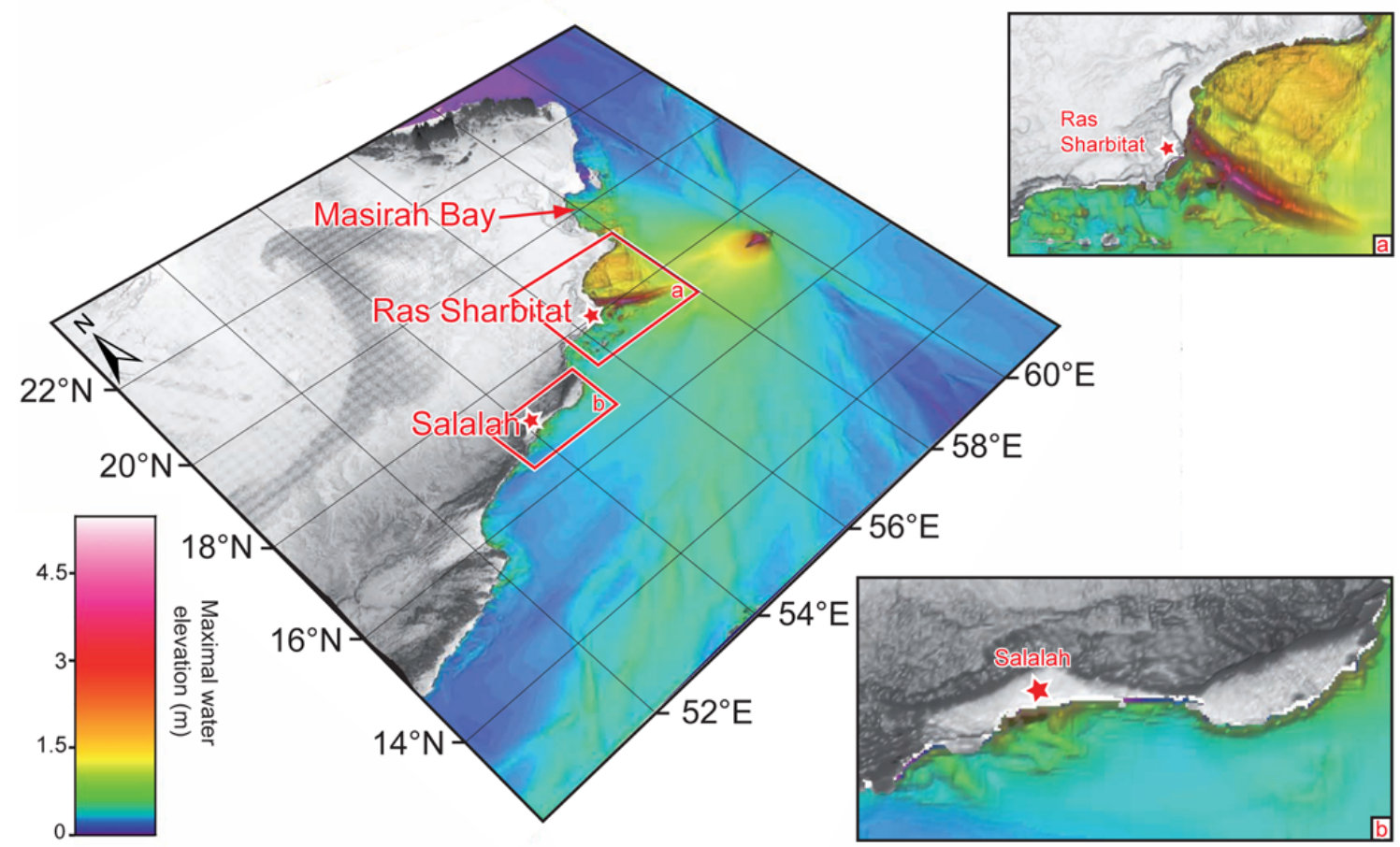

Fig. 4. Maximum water elevations computed after a $8000 \mathrm{~s}$ simulation for a dynamic viscosity value at $500 \mathrm{~m} \mathrm{~s}^{-2}$. Insets show the maximum water elevations computed around Ras Sharbitat (inset a) and Salalah (inset b).

Synolakis, 2008), and stronger than amplitude values calculated for the 1945 Makran event $(<0.4 \mathrm{~m}$ ) (Okal and Synolakis, 2008).

As already explained earlier, the modeled tsunami height values obtained with a $1 \mathrm{~km}$ cell size are not strictly run-up values since the flooding is not modeled, and they would be probably amplified using refined bathymetric grids close to the coast due to the tsunami shoaling effect which is all the more well accounted for as the grid spacing is lower. Depending on the local bathymetric slopes and configuration, these waves may locally be greatly amplified and yield amplitudes above $3 \mathrm{~m}$ at least. Another source of uncertainty is the nondispersive numerical model that is not able to account for frequency dispersion inherent in tsunamis with short wavelengths, thus especially for landslide triggering. However the large extent of the $17^{\circ} 20^{\prime} \mathrm{N}$ landslide probably precludes a strong influence of frequency dispersion, specially because the wavelengths considered here are not so short with respect to the water depth, and also because the distance of propagation is not large enough to offer a significant effect of this dispersion. On the other hand, amplitude dispersion may locally occur on the continental shelf (Geist et al., 2009) and especially near Ras Sharbitat, leading to relatively attenuated wave heights in this area.

Other submarine landslides identified off Salalah on the Dhofar margin (Fig. 1) (Bache et al., 2010) may potentially be a more important source of tsunami hazard in the area.
This study further demonstrates that submarine landslides occurring along remote and deep oceanic ridges (only blanketed by pelagic material) can be a source of infrequent but quite significant tsunamis. The present-day state of slope stability along the Owen Ridge remains unknown, and it is difficult to assess if a voluminous landslide is bound to occur in the near future. Other places in the world are potentially vulnerable to this type of tsunami sources. For instance, in the Atlantic Ocean, the Gorringe Bank rock avalanche (Zitellini et al., 2009), which is $60-80 \mathrm{~km}^{3}$ in volume and $26-30 \mathrm{kyr}$ old, could have generated a potentially destructive tsunami on densely populated Portuguese, Spanish (Lo lacono et al., 2012) and Moroccan coastlines. In contrast with the numerous large landslides observed along the Owen Ridge, the Gorringe Bank rock avalanche is the only large landslide $\left(>1 \mathrm{~km}^{3}\right)$ observed along the Gorringe Bank since its Miocene uplift (Jiménez-Munt et al., 2010), which is conspicuous with regards to the high frequency of large magnitude earthquakes $\left(M_{\mathrm{w}}>6\right)$ in the area (Baptista and Miranda, 2009). This contrasts with slope failures on the nearby Portuguese margin that produced turbiditic deposits whose estimated ages correlate well with the most important historic earthquakes and tsunamis (Gràcia et al., 2010). This comparison suggests that conditions for a large slope failure to occur along the Gorringe Bank might bring together a sufficient volume of sediment (limited by slow pelagic sedimentation rates) and a favourable state of consolidation. The 
state of slope stability of remote oceanic ridges similar to the Owen Ridge or the Gorringe Bank needs to be further investigated, but the overall return periods of such deep-sea seated tsunamigenic instabilities are not expected to be less than several thousands of years.

Acknowledgements. We are indebted to the Captain Geoffroy de Kersauson, officers, and crew members of the BHO BeautempsBeaupré, and to the French Navy hydrographs Vincent Lamarre and Yves-Marie Tanguy, and the hydrographic team of the 'Groupe Océanographique de l'Atlantique', for their assistance in data acquisition. The manuscript benefits from helpful and constructive comments from H. Fritz and an anonymous reviewer. We warmly thank Matthias Delescluse, Pierpaolo Dubernet and Nasser Bacha for their help and their technical assistance. We acknowledge the support of SHOM, IFREMER, CEA (LRC Yves Rocard), UPMC and INSU-CNRS for this study.

Edited by: I. Didenkulova

Reviewed by: H. M. Fritz and one anonymous referee

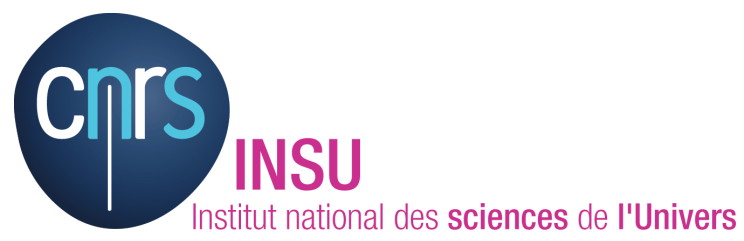

The publication of this article is financed by CNRS-INSU.

\section{References}

Alcrudo, F. and Garcia-Navarro, P.: A high-resolution Godunovtype scheme in finite volumes for the $2 \mathrm{D}$ shallow water equations, Int. J. for. Num. Meth. Fluids, 16, 489-505, 1993.

Bache, F., Leroy, S., Baurion, C., Robinet, J., Gorini, C., Lucazeau, F., Razin, P., d'Acremont, E., and Al-Toubi, K.: Post-rift uplift of the Dhofar margin (Gulf of Aden), Terra nova, 23, 11-18, doi:10.1111/j.1365-3121.2010.00975.x, 2010.

Baptista, M. A. and Miranda, J. M.: Revision of the Portuguese catalog of tsunamis, Nat. Hazards Earth Syst. Sci., 9, 25-42, doi:10.5194/nhess-9-25-2009, 2009.

Bourget, J., Zaragosi, S., Rodriguez, M., Fournier, M., Garlan, T., and Chamot-Rooke, N.: Late Quaternary megaturbidites of the Indus Fan: Origin and stratigraphic significance, Mar. Geol., 336, 10-23, doi:10.1016/j.margeo.2012.11.011, 2013.

Donato, S. V., Reinhardt, E. G., Boyce, J. I., Rothaus, R., and Vosmer, T.: Identifying tsunami deposits using bivalve shell taphonomy, Geology, 36, 199-202, 2008.

Donato, S. V., Reinhardt, E. G., Boyce J. I., Pilarczyk, J. E., and Jupp, B. P.: Particle-size distribution of inferred tsunami deposits in Sur Lagoon, Sultanate of Oman. Mar. Geol., 257, 54-64, 2009.

Fournier, M., Patriat, P., and Leroy, S.: Reappraisal of the ArabiaIndia-Somalia triple junction kinematics, Earth Planet. Sci. Lett., 189, 103-114, 2001.

Fournier, M., Chamot-Rooke, N., Petit, C., Fabbri, O., Huchon, P., Maillot, B., and Lepvrier, C.: In-situ evidence for dextral active motion at the Arabia-India plate boundary, Nat. Geosci., 1, 54 58, doi:10.1038/ngeo.2007.24, 2008.

Fournier, M., Chamot-Rooke, N., Rodriguez, M., Huchon, P., Petit, C., Beslier, M.-O., and Zaragosi, Z.: Owen Fracture Zone: the Arabia-India plate boundary unveiled, Earth Planet. Sci. Lett., 302, 247-252, doi:10.1016/j.epsl.2010.12.027, 2011.

Fritz, H. M., Mohammed, F., and Yoo, J.: Lituya Bay Landslide Impact Generated Mega-Tsunami 50th Anniversary, Pure Appl. Geophys., 166, 153-175, doi:10.1007/s00024-008-04354, 2009.

Fritz, H. M, Blount, C. D., Albusaidi, F. B., and Al-Harthy, A. H. M.: Cyclone Gonu Storm Surge in Oman, Estuar. Coast. Shelf Sci., 86, 102-106, doi:10.1016/j.ecss.2009.10.019, 2010.

Gràcia, E., Vizcaino, A., Escutia, C., Asioli, A., Rodés, A., Pallàs, R., Garcia-Orellana, J., Lebreiro, S., and Goldfinger, C.: Holocene earthquake record offshore Portugal (SW Iberia): testing turbidite paleoseismology in a slow-convergence margin, Quaternary Sci. Rev., 29, 1156-1172, 2010.

Geist, E. L., Lynett,P. J., and Chaytor,J. D.: Hydrodynamic modeling of tsunamis from the Currituck landslide, Mar. Geol., 264, 41-52, 2012.

Gordon, R. G. and DeMets, C.: Present-day motion along the Owen fracture zone and Dalrymple trough in the Arabian Sea, J. Geophys. Res., 94, 5560-5570, 1989.

Heidarzadeh, M., Pirooz, M. D., Zaker, N. H., Yalciner, A. C., Mokhtari, M., and Esmaeily, A.: Historical tsunami in the Makran Subduction Zone off the southern coasts of Iran and Pakistan and results of numerical modeling, Ocean Eng., 35, 774786, 2008.

Heinrich, P., Piatanesi, A., Okal, E. A., and Hébert, H.: Near-field modeling of the July 17, 1998 tsunami in Papua New Guinea, Geophys. Res. Lett., 27, 3037-3040, 2000.

Heinrich, P., Piatanesi, A., and Hébert, H.: Numerical modelling of tsunami generation and propagation from submarine slumps: the 1998 Papua New Guinea event, Geophys. J. Int., 145, 97-111, 2001.

Hoffman, G., Reicherter, K., Wiatr, T., Grützner, C., and Rausch, T.: Block and boulder accumulations along the coastline between Fins and Sur (Sultanate of Oman): tsunamigenic remains?, Nat. Hazards, 65, 851-873, 2013.

Jaiswal, R. K., Singh, A. P., and Rastogi, B. K.: Simulation of the Arabian Sea Tsunami propagation generated due to 1945 Makran Earthquake and its effect on western parts of Gujarat (India) Nat. Hazards, 48, 245-258, doi:10.1007/s11069-008-9261-3, 2009.

Jiang, L. and Leblond, P.: The coupling of a submarine slide and the surface waves which it generates, J. Geophys. Res., 97, 731-744, 1992.

Jiang, L. and Leblond, P.: Numerical modelling of an underwater Bingham plastic mudslide and the waves which it generates, J. Geophys. Res., 98, 304-317, 1993.

Jiménez-Munt, I., Fernàndez, M., Vergés, J., Afonso, J. C., GarciaCastellanos, D., and Fullea, J.: Lithospheric structure of the Gorringe Bank: Insights into its origin and tectonic evolution, Tectonics, 29, TC5019, doi:10.1029/2009TC002458, 2010.

Jourdan, B.: Tsunamis of the Arabian peninsula : a guide of historic events, Sci. Tsunami Hazards, 27, No. 1, 31-46, 2008.

Labbé, M., Donnadieu, C., Daubord, C., and Hébert, H.: Refined numerical modeling of the 1979 tsunami in Nice (French Riviera): Comparison with coastal data, J. Geophys. Res., 117, F01008, 
doi:10.1029/2011JF001964, 2012.

Lo lacono, C., Gràcia, E., Zaniboni, F., Pagnoni, G., Tinti, S., Bartolomé, R., Masson, D. G., Wynn, R. B., Lourenço, N., Pinto de Abreu, M., Danobeitia, J., and Zitellini, N.: Large, deepwater slope failures : implications for landslide-generated tsunamis, Geology, 40, 931-934, doi:10.1130/G33446.1, 2012.

Mangeney, A., Heinrich, V., and Roche, V.: Analytical and numerical solutions of dam-break problem for application to water floods, debris and dense snow avalanche, Pure Appl. Geophys., 157, 1081-1096, 2000.

McAdoo, B. G., Pratson, L. F., and Orange, D. L.: Submarine landslide morphology, US continental slope, Mar. Geol., 169, 103136, 2000.

McEwen, A. and Malin, M.: Dynamics of Mount St Helens'1980 pyroclastic flows, rockslide-avalanche, lahars and blast, J. Volc. Geotherm. Res., 37, 205-231, 1989.

Mohammed, F. and Fritz, H. M.: Physical modeling of tsunamis generated by three-dimensional deformable granular landslides, J. Geophys. Res. Oceans, 117, C11015, doi:10.1029/2011JC007850, 2012.

Mulder, T. and Cochonat, P.: Classification of offshore mass movements, J. Sediment. Res., 66, 43-57, 1996.

Norem, H., Locat, J., and Schieldrop, B.: An approach to the physics and the modelling of submarine flowslides, Mar. Geotech., 9, 93$111,1991$.

Okal, E. A. and Synolakis, C. E.: Far-field tsunami hazard from mega-thrust earthquakes in the Indian Ocean, Geophys. J. Int., 172, 995-1015, doi:10.1111/j.1365-246X.2007.03674.x, 2008.

Okal, E. A., Fritz, H. M., Synolakis, C. E., Raad, P. E., Al-Shijbi, Y., and Al-Saifi, M.: Field Survey of the 2004 Indonesian Tsunami in Oman, Earthq. Spectra, 22, S203-S218, 2006.

Pilarczyk, J. E. and Reinhardt, E. G.: Testing foraminiferal taphonomy as a tsunami indicator in a shallow arid system lagoon: Sur, Sultanate of Oman. Mar. Geol., 295-298, 128-136, doi:10.1016/j.margeo.2011.12.002, 2012.

Pilarczyk, J. E., Reinhardt, E. G., Boyce, I. J., Schwarcz, H. P., and Donato, S. V.: Assessing surficial foraminiferal distributions as an overwash indicator in Sur Lagoon, Sultanate of Oman, Mar. Micropaleontol., 80, 62-73, 2011.

Quittmeyer, R. C. and Kafka, A. L.: Constraints on plate motions in southern Pakistan and the northern Arabian Sea from the focal mechanisms of small earthquakes, J. Geophys. Res., 89, 2444 2458, 1984.

Rodriguez, M., Fournier, M., Chamot-Rooke, N., Huchon, P., Bourget, J., Sorbier, M., Zaragosi, S., and Rabaute, A.: Neotectonics of the Owen Fracture Zone (NW Indian Ocean): structural evolution of an oceanic strike-slip plate boundary, Geochem. Geophys. Geosyst., 12, Q12006, doi:10.1029/2011GC003731, 2011.
Rodriguez, M., Fournier, M., Chamot-Rooke, N., Huchon, P., Zaragosi, S., and Rabaute, A.: Mass wasting processes along the Owen Ridge (NW Indian Ocean), Mar. Geol., 326-328, 80-100, doi:10.1016/j.margeo.2012.08.008, 2012.

Savage, S. and Hutter, K.: The motion of a finite mass of granular material down a rough incline, J. Fluid. Mech., 199, 177-215, 1989.

Shipboard Scientific Party: Site 731, in: Proc. ODP, Init. Repts., edited by: Prell, W. L., Niitsuma, N., Emeis, K. C., Al-Sulaiman, Z. K., Al-Tobbah, A. N. K., Anderson, D. M., Barnes, R. O., Bilak, R. A., Bloemendal, J., Bray, C. J., Busch, W., Clemans, S. C., de Menocal, P., Debrabant, P., Hayashida, A., Hermelin, O. J. R., Jarrad, R. D., Krissek, L. A., Kroon, D., Murray, D. W., Nigrini, C.A., Pedersen, T. F., Ricken, W, Shimmield, G. B., Spaulding, S. A., Takayama, T., Lo ten Haven, H., and Weedon, G. P., Leg 117, College Station, TX (Ocean Drilling Program), 585-652, 1989.

Sousa, J. and Voight, B.: Continuum simulation of flow failures, Geotechnique, 41, 515-538, 1991.

Sousa, J. and Voight, B.: Multiple pulsed debris avalanche emplacement at Mount St Helens in 1980: Evidence from numerical continuum flow simulations, J. Volc. Geotherm. Res., 66, 227-250, 1995.

Tappin, D. R.: Digital elevation models in the marine domain: investigating the offshore tsunami hazard from submarine landslides, Geol. Soc. London, spec. pub., 345, 81-101, 2010.

Tappin, D. R., Watts, P., McMurtry, G. M., Laffoy, Y., and Matsumoto, T.: The Sissano, Papua New Guinea tsunami of July 1998 - offshore evidence on the source, Mar. Geol., 175, 1-23, 2001.

Tappin, D. R., Watts, P., and Grilli, S. T.: The Papua New Guinea tsunami of 17 July 1998: anatomy of a catastrophic event, Nat. Hazards Earth Syst. Sci., 8, 243-266, doi:10.5194/nhess-8-2432008, 2008.

Trifunac, M. D. and Todorovska, M. I.: A note on differences in tsunami source parameters for submarine slides and earthquakes, Soil Dynam. Earthq. Eng., 22, 143-155, 2002.

Tripsanas, E. K., Piper, D. J. W., Jenner, K. A., and Bryant, W. R.: Submarine mass-transport facies: new perspectives on flow processes from cores on the eastern North American margin, Sedimentology, 55, 97-136, 2008.

Zitellini, N., Gràcia, E., Matias, L., Terrinha, P., Abreu, M. A., DeAlteriis, G., Henriet, J. P., Dañobeitia, J. J., Masson, D. G., Mulder, T., Ramella, R., Somoza, L., and Diez, S.: The quest for the Africa-Eurasia plate boundary west of the Strait of Gibraltar, Earth Planet. Sci. Lett., 280, 13-50, doi:10.1016/j.eps1.2008.12.005, 2009. 